
VOLUME 10 NOMOR 6 DESEMBER 2021

ISSN : 2303-1514 | E-ISSN : 2598-5949

\title{
PENGEMBANGAN MEDIA VIDEO PEMBELAJARAN ANIMASI BERBASIS KINEMASTER UNTUK MENINGKATKAN EFEKTIVITAS PADA MATA PELAJARAN IPA SISWA KELAS IV SDN KEDALEMAN IV
}

\author{
Nurdiana Siti Alifa ${ }^{1}$, Syadeli Hanafi ${ }^{2}$, Lukman Nulhakim ${ }^{3}$ \\ 1,2,3 Universitas Sultan Ageng Tirtayasa, Serang, Indonesia \\ lalifasitinurdiana@gmail.com, ${ }^{3}$ lukman9479@gmail.com
}

\section{DEVELOPING KINEMASTER-BASED ANIMATED VIDEOS AS LEARNING MEDIA TO INCREASE STUDENTS' EFFECTIVENESS IN SCIENCE LEARNING AT GRADE IV OF SDN KEDALEMAN IV}

ARTICLE HISTORY

Submitted:

26 Juni 2021

$26^{\text {th }}$ June 2021

Accepted:

10 Oktober 2021

$10^{\text {th }}$ October 2021

Published:

27 Desember 2021

$27^{\text {th }}$ December 2021

\section{ABSTRACT}

\begin{abstract}
Online learning during the pandemic needs animated videos as learning media in science subjects at the fourth grade of elementary school. This research aimed to develop kinemaster-based animation learning videos in science subjects using the ADDIE development model (analyze, design, development, implementation, and evaluation). The stages to be carried out included (a) analyzing the knowledge or competence of the target, the characteristics of the target, and the equipment that supports the use of the media, $(b)$ designing the transferred information from the analysis phase into the form of a document aiming of making a learning video, $(c)$ developing learning videos; the core of this activity was taking pictures or animated motion videos with an internet connection, in which the video development was carried out by using several applications, namely the kinemaster and the tubemate application. The implementation phase included implementing learning videos for fourth-grade elementary school students. Finally, the evaluation stage included the assessment of the learning media in the form of a questionnaire. The results of this development research were the animated learning videos for science learning to assist students in increasing their understanding of material concepts. The validation results from material experts showed an average of $94.3 \%$ on material, and the learning aspects with qualitative criteria were very feasible. Then, the result from media experts got an average of $87 \%$ with very decent qualitative criteria. At the same time, the students' responses obtained an average of $97 \%$, with very good criteria. Thus, this learning video facilitated the learning process from home so that students easily understood the concepts of science subjects on the material of force and motion of objects.
\end{abstract}

Keywords: Animation Learning Video, Kinemaster, and Students' Effectiveness

Abstrak: Pembelajaran daring dimasa pandemi sangat dibutuhkan media pembelajaran video animasi dalam mata pelajaran IPA dikelas IV SD. Tujuan dari penelitian adalah untuk mengembangkan video pembelajaran animasi berbasis kinemaster pada mata pelajaran IPA dengan menggunakan model pengembangan ADDIE ( analyze, design, development, implementation, dan evaluation). Tahapan yang akan dilakukan yaitu meliputi analisis pengetahuan atau kompetensi sasaran, karakteristik sasaran, dan peralatan yang menunjang penggunaan media; tahap perancangan yang dilakukan meliputi pemindahan informasi dari fase analisis kedalam bentuk dokumen yang menjadi tujuan dibuatnya video pembelajaran; tahap pengembangan yang dilakukan meliputi: kegiatan produksi atau mengembangkan video pembelajaran, inti dari kegiatan ini adalah pengambilan gambar atau video gerak animasi dengan koneksi internet, dimana pengembangan video dilakukan dengan menggunakan beberapa aplikasi yaitu aplikasi kinemaster, dan aplikasi tubemate. Tahap implementasi yang dilakukan meliputi video pembelajaran yang diterapkan pada siswa kelas IV SD. Dan tahap evaluasi melipuuti kegiatan penilaian media berupa angket. Hasil penelitian pengembangan ini yaitu dihasilkannya video pembelajaran animasi pada mata pelajaran IPA yang bisa digunakan oleh guru dalam pembelajaran untuk membantu siswa dalam meningkatkan pemahaman pada konsep materi berdasarkan hasil validasi ahli materi dengan rata-rata $94.3 \%$ pada aspek materi dan pembelajaran dengan kriteria kualitatif sangat layak, serta ahli media dengan rata-rata $87 \%$ dengan kriteria kualitatif sangat layak. Sedangkan pada respon siswa diperoleh rata-rata 97\% dengan kriteria sangat baik. Dengan demikian, video pembelajaran ini bisa digunakan untuk membantu proses belajarnya dari rumah sehingga siswa dapat dengan mudah memahami konsep mata pelajaran IPA pada materi gaya dan gerak benda.

Kata Kunci: Video Pembelajaran Animasi, Kinemaster, dan Efektivitas Pembelajaran IPA 


\section{CITATION}

Alifa, N. S., Hanafi, S., \& Nulhakim, L. (2021). Pengembangan Media Video Pembelajaran Animasi Berbasis Kinemaster Untuk Meningkatkan Efektivitas Pada Mata Pelajaran IPA Siswa Kelas IV SDN Kedaleman IV. Primary: Jurnal Pendidikan Guru Sekolah Dasar, 10 (6), 15541564. DOI: http://dx.doi.org/10.33578/jpfkip.v10i6.8395.

\section{PENDAHULUAN}

Pembelajaran berbasis teknologi sedang marak digunakan pada masa pandemi covid-19. Pada masa pandemi covid-19 menuntut guru dan siswa untuk beradaptasi dengan kebiasaan baru dalam belajar yaitu pembelajaran secara daring. Guru seharusnya peka terhadap kemajuan teknologi pembelajaran untuk meningkatkan motivasi, minat, dan mutu pembelajaran siswa. Dengan demikian di masa pandemik ini siswa tidak hanya belajar menggunakan modul/bahan ajar yang dibagikan saja tetapi perlu juga menggunakan metode belajar yang bervariasi sehingga siswa bisa tertarik untuk belajar. Proses pembelajaran dalam pendidikan secara khusus dapat diwujudkan pada kegiatan pembelajaran disekolah. Untuk mencapai tujuan tersebut, pembelajaran dapat dilakukan melalui kegiatan belajar secara berkualitas. Jika siswa mengalami kesulitan dalam memahami materi pelajaran pada saat pembelajaran berlangsung maka siswa diharapkan menggunakan media pembelajaran online yang sangat berpengaruh terhadap hasil dalam peningkatan pemahaman pada materi tersebut. (Sulthon, 2017).

Hasil belajar yang baik dapat dicapai melalui interaksi, dari berbagai faktor yang saling mendukung satu sama lain. Penggunaan media pembelajaran merupakan salah satu faktor penting dalam kegiatan pembelajaran disekolah. (Hamdayan, 2017). Guru seharusnya peka terhadap kemajuan teknologi pembelajaran untuk meningkatkan motivasi, minat, dan mutu pembelajaran siswa. Dengan demikian di masa pandemik ini siswa tidak hanya belajar menggunakan modul/bahan ajar yang dibagikan saja tetapi perlu juga menggunakan metode belajar yang bervariasi sehingga siswa bisa tertarik untuk belajar. Dari hasil observasi pendahuluan yang dilakukan peneliti di SDN Kedaleman IV dari beberapa kelas di kelas IV yang dijadikan obyek observasi dihasilkan beberapa data yakni pembelajaran dilakukan tanpa menggunakan media dalam pembelajaran melalui daring hanya metode ceramah yang dipakai oleh guru untuk penyampaian materi sehingga hasil yang diharapkan tidak sesuai dengan tujuan pembelajaran yang diharapkan guru, serta turunnya minat belajar siswa karna pembelajaran terasa monoton dan sangat membosankan.

Media Pembelajaran mempunyai peranan sangat penting dalam kesatuan proses belajar mengajar yang tidak dapat dipisahkan dari dunia pendidikan. Media pembelajaran yaitu segala sesuatu yang dapat digunakan untuk menyalurkan pesan pengirim kepada penerima, sehingga dapat merangsang pikiran, perasaan, perhatian, dan minat peserta didik untuk belajar secara optimal.Media dapat berperan untuk mengatasi kebosanan dan kejenuhan dalam belajar di kelas, oleh karena itu guru dituntut memberikan motivasi pada peserta didik dengan memanfaatan media yang tidak hanya ada di dalam kelas, akan tetapi juga yang ada di luar kelas. (Adi, 2019). Jika hal itu dimanfaatkan maka tujuan pembelajaran akan tercapai. Sebaliknya apa yang terjadi jika media pembelajaran tidak ada, maka yang terjadi adalah mengalami kesulitan dalam mengajar, materi menjadi monoton dan siswa merasa bosan dan jenuh dengan apa yang diajar oleh pendidik sehingga tujuan pembelajaran tidak tercapai. Oleh karena itu, untuk meningkatkan kualitas belajar perlu digunakan media pembelajaran dalam mengajar.

\section{KAJIAN TEORI}

Bagian metode ini harus dapat menjelaskan tentang metode penelitian yang digunakan, termasuk tempat, waktu penelitian dan bagaimana prosedur pelaksanaannya. alat, bahan, media atau instrumen penelitian harus dijelaskan 
dengan baik. Jika perlu dan penting, ada lampiran mengenai kisi-kisi dari instrumen atau penggalan bahan yang digunakan sekedar memberikan contoh bagi para pembaca. Apabila ada rumusrumus statistika yang digunakan sebagai bagian dari metode penelitian, sebaiknya rumus yang sudah umum digunakan tidak ditulis. Misalnya ada ketentuan spesifik yang ditetapkan oleh peneliti dalam rangka mengumpulkan dan menganalisis data penelitian dapat dijelaskan pada bagian metode ini. Penulis disarankan menyampaikan sumber rujukan atas metode yang digunakan.

Keunggulan video pembelajaran yaitu bisa mengakomodir audio dan visual yang bisa memberikan nuansa baru dan menarik bagi siswa (Oktaviani, 2019). Aplikasi online juga memanfaatkan media audio-visual seperti video pembelajaran. Kelemahan aplikasi ini yaitu terkadang konten di dalamnya kurang kontekstual dengan siswa yang ada di SDN Kedaleman IV. Oleh karena itu perlu pengembangan video pembelajaran yang lebih kontekstual dalam belajar bagi siswa di SDN Kedaleman IV dalam bentuk video pembelajaran. Video animasi merupakan salah satu media yang dapat dimanfaatkan dalam membantu kegiatan belajar mengajar. Video animasi dapat digunakan dalam pembelajaran serta dapat membantu guru dalam menyampaikan materi. Adanya video animasi dalam pembelajaran dapat pula membantu siswa memahami materi yang abstrak menjadi lebih konkret, sehingga siswa tidak hanya menghayal dan membayangkan saja. Terdapat berbagai keuntungan dalam penggunaan animasi pada pembelajaran seperti di antaranya animasi yang di desain menarik akan membuat pembelajaran menjadi tidak membosankan serta dapat memotivasi belajar siswa. Animasi dapat didesain untuk menyampaikan berbagai jenis materi pelajaran sesuai dengan indikator pembelajaran, serta penggunaan animasi dapat menekan biaya produksi dibandingkan dengan menggunakan pemeran yang sebenarnya.(Musdayat, 2017)

Media animasi ini sangat membatu pembelajaran karna memperluas ilmu pengetahuan serta wawasan spiritual peserta didik. Dengan adanya media animasi siswa dapat mendengarkan dan melihat secara langsung bacaan teks serta gerakan - gerakan animasi berupa gambar sesuai pada materi yang akan disampaikan oleh guru. Dalam pengembangan media animasi ini, penulis mengharapkan peserta didik bisa lebih semangat dan mandiri dalam proses pembelajaran.

Penggunaan program video dalam pembelajaran harus mampu melibatkan peserta didik dalam proses belajar. Peserta didik yang terlibat secara intensif dengan media video dan materi pelajaran yang ada didalamnya akan belajar lebih mudah dan mampu mencapai kompetensi yang diinginkan. Kualitas teknis program video yang digunakan untuk keperluan pembelajaran harus dalam keadaan baik dalam faktor kebisingan pada sebuah program audio akan sangat mengganggu kelancaran aktivitas pembelajaran. Kinemaster adalah aplikasi pengeditan video berfitur lengkap dan profesional untuk perangkat iOS dan Android. Ini mendukung banyak lapisan video, audio, gambar, teks dan efek. Dilengkapi dengan berbagai alat yang memungkinkan pengguna membuat video berkualitas tinggi. Dengan Kinemaster, editor memiliki kendali tertinggi atas video mereka terutama dalam hal memangkasnya. Aplikasi ini memungkinkan mereka memotong dengan bingkai, serta memungkinkan untuk menjadi sangat tepat dalam transisi dan efeknya.

IPA merupakan suatu ilmu yang mengkaji segala sesuatu tentang gejala yang ada dialam, baik benda hidup maupun benda mati (Hermiyanty,dkk.2017) Dalam melatih keterampilan - keterampilan proses dasar IPA dan sikap ilmiah, diperlukan suatu pembelajaran yang tidak hanya siswa berperan sebagai penerima namun siswa juga harus mengalami sendiri pengalaman dan memahami ilmu tersebut. Hakikat IPA dapat dipandang dari segi proses, produk dan pengembangan sikap yang merupakan suatu kumpulan pengetahuan yang diperoleh tidak hanya produk saja, akan tetapi juga mencakup pengetahuan seperti keterampilan keingintahuan, keteguhan hati, dan juga keterampilan dalam hal melakukan penyelidikan 
ilmiah.

(Sumarni,

dkk

2015)

Pembelajaran IPA menekankan kegiatan-kegiatan belajar yang memberikan pengalaman langsung kepada siswa untuk mengembangkan potensi yang dimiliki oleh siswa. Pendidikan IPA diarahkan untuk "mencari tahu" dan "berbuat" sehingga siswa dapat memperoleh pemahamannya mengenai alam di sekitarnya dengan lebih mendalam.

\section{METODE PENELITIAN}

Penelitian ini menggunakan model pengembangan ADDIE (analyze, design, development, implementation, and evaluation). Berbagai tahapan dalam model dilakukan secara berurutan. Setiap tahap memiliki fungsi dan peran yang sangat mendukung keberhasilan penggunaan model. Mengacu pada model pengembangan ADDIE menurut (Tegeh, dkk 2013) "yang digunakan dalam pengembangan media video pembelajaran dapat dipaparkan langkah-Iangkah operasional mulai dari tahap analisis, tahap perancangan, tahap pengembangan, tahap implementasi, dan tahap evaluasi”.

Pada tahap analisis, peneliti melakukan kegiatan: (1) menemukan permasalahan belajar, (2) evaluasi media pembelajaran yang telah di gunakan untuk menentukan karakteristik produk media yang akan di kembangkan, (3) analisis karakter produk yang akan dikembangkan. Pada tahap desain peneliti melakukan kegiatan : (1) menyusun desain tampilan video animasi, (2) menyusun komponen video animasi (3) merancang struktur materi, (4) membuat bagan alur (flowchart), (5) merancang sketsa (storyboard). Pada tahap pengembangan peneliti melakukan kegiatan : (1) membuat media yang sesuai dengan kerangka kerja, (2) menyusun instrumen validasi, (3) melakukan uji coba ahli media, materi, guru, dan siswa, (4) me-review atau merevisi media yang dikembangkan. Pada tahap implementasi peneliti melakukan kegiatan : (1) mengimplementasikan media yang digunakan, (2) menyebarkan angket penilaian siswa dan guru, (3) menguji pengaruh video animasi terhadap hasil belajar siswa.
Pada tahap evaluasi, peneliti melakukan kegiatan: (1) melakukan evaluasi kegiatan media berdasarkan persepsi siswa, kualitas pembelajaran, dan ketercapaian kompetensi siswa (2) memberikan post tes setelah menyimak media pembelajaran sesuai materi. Animasi pada materi gaya dan gerak benda. Potensi ini tersedia karena adanya sarana dan prasarana seperti akses jaringan internet, HP, dan laptop.

\section{HASIL PENELITIAN DAN PEMBAHASAN}

\section{Hasil Tahapan Pengembangan Media Pembelajaran}

Hasil Pengembangan yang dilakukan pada penelitian ini adalah menghasilkan media video animasi pembelajaran berbasis kinemaster pada mata pelajaran IPA dikelas IV. Berikut tahapan dalam mengembangkan media video pembelajaran animasi , antara lain :

a) Tahap Potensi dan Masalah

Potensi yang diperoleh dimanfaatkan untuk dijadikan nilai lebih dalam pengembangan media video pembelajaran animasi pada materi gaya dan gerak benda. Potensi ini tersedia karena adanya sarana dan prasarana seperti akses jaringan internet, HP, dan laptop.Permasalahan yang dihadapi oleh guru dan peserta didik diantaranya kurangnya variasi media yang digunakan dalam proses pembelajaran, sehingga peserta didik mengalami kesulitan dalam memahami dan membayangkan proses pembelajaran dengan materi gaya dan gerak benda melalui penjelasan secara ceramah saja dengan bersumber pada buku pelajaran siswa saja dan materi berupa slide yang diberikan oleh guru, tanpa adanya media perantara yang bisa membuat peserta didik untuk dapat memahami pelajaran tersebut. Kurangnya penggunaan media dalam kegiatan pembelajaran khususnya pada kelas IV mengakibatkan peserta didik lebih cepat jenuh dan tidak dapat fokus pada materi pelajaran yang sedang diajarkannya khususnya pada pelajaran IPA. Tingkat kemampuan guru dalam mengoperasikan PC atau laptop bisa terbilang cukup baik akan tetapi keahlian guru dalam mengembangkan media yang berbasis komputer kurang baik, hal ini dibuktikan belum adanya 
guru dalam membuat video animasi pada pelajaran IPA.

b) Pengumpulan Informasi

Pada tahap ini, peneliti mengumpulkan data - data yang dapat mendukung pengembangan produk. Diperoleh data bahwa sekolah tersebut belum terdapat media pembelajaran IPA berupa video pemebelajaran animasi berbasis kinemaster pada materi gaya dan gerak benda dengan output youtube dan kepingan berupa kepingan Compact Disk (CD), sehingga peneliti dapat melakukan analisis kebutuhan untuk siswa dan guru, analisis materi dalam pengembangan produk ini pada materi gaya dan gerak benda disesuaikan pada kompetensi dasar sesuai dengan kurikulum 2013.

c) Desain Produk

Desain produk disesuaikan dengan menyesuaikan pada kompetensi inti, kompetensi dasar, indikator dan tujuan pembelajaran, serta silabus berdasarkan kurikulum 2013. Video pembelajaran dirancang dengan tampilan yang menarik dan bahasa yang mudah dipahami serta berisi materi. Dikumpulkan materi - materi yang dapat dijadikan sebagai bahan referensi dalam penyusunan kerangka video dengan materi gaya dan gerak benda. Kerangka yang telah ditentukan maka dilakukan perancangan awal untuk mendapatkan cerita dalam video pembelajaran disesuaikan dengan kompetensi dasar dari judul, tujuan pembelajaran dan isi materi. Adapun proses yang dilakukan untuk membuat desain produk yaitu :

1) Pembuatan media video pembelajaran animasi diawali dengan pembuatan rancangan dalam bentuk alur (flowchart) yang berisi simbol simbol grafis yang menunjukkan arah alur kegiatan dan data - data.

2) Membuat storyboard pada tahap ini didalamnya terdapat penjelasan terkait video seperti visual, narasi, dan keterangan di storyboard kemudian memvalidasikannya. Storyboard dibuat untuk mempermudah memvisualisasikan ide yang dimiliki agar lebih tertata. Pembuatan storyboard secara detail mungkin sampai dengan perencanaan pada pengembangan dengan menggunakan aplikasi Kinemaster.

3) Mempersiapkan skrip, pada saat pembuatan storyboard diikuti dengan penulisan skrip. Skrip disusun dengan menggunakan format tiga kolom yang berisi scene, visual dan audio/narasi. Scene menunjukkan nomor slide yang dibuat pada aplikasi kinemaster. Visual menampilkan tampilan pada slide diaplikasi kinemaster. Kolom narasi berisi naratif untuk narator agar memperjelas tayangan dalam video.

d) Validasi Desain

Validasi desain produk media pembelajaran ini dilakukan oleh dua bidang ahli, yaitu ahli media dan ahli materi. Ahli media divalidasi oleh Dr. Suhendar, S.Pd.,M.T dan ahli materi divalidasi oleh Dr. Rida Oktorida Khastini, S.Si.,M.Si. Berdasarkan lembar instrumen penilaian. Validasi ahli yang telah diisi, maka tahap selanjutnya adalah menghitung skor rata-rata dari setiap kriteria penilaian yang telah diberikan oleh setiap validator dan menghitung presentase produknya. Hasil deskripsi data validasi diperoleh dengan merekapitulasi hasil validasi tersebut dalam tabel rekapitulasi. 1) Validasi Ahli Media 2) Validasi Ahli Media. Tujuan sebelum melakukan uji coba validasi oleh ahli media adalah untuk mengetahui keabsahan media pembelajaran yang akan dikembangkan. Untuk mendapatkan informasi, kritik, dan saran agar media pembelajaran video animasi menjadi produk yang berkualitas secara kegrafikan. Validator ahli media pada pengembangan video pembelajaran animasi ini yaitu Dr. Suhendar, S.Pd.,M.T salah satu dosen Universitas Sultan Ageng Tirtayasa. Penilaian diberikan melalui lembar instrumen penilaian validasi media dengan skor maksimal masing-masing indikator adalah lima sedangkan skor minimum adalah satu. Adapun hasil validasi yang diperoleh dari ahli media adalah sebagai berikut : 


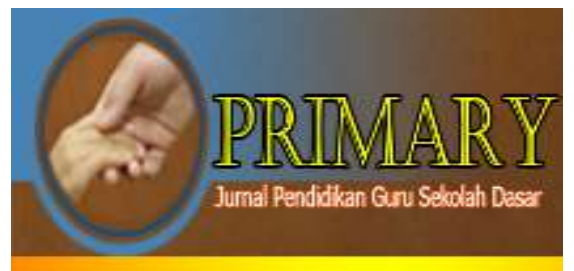

\section{PRIMARY: JURNAL PENDIDIKAN GURU SEKOLAH DASAR \\ VOLUME 10 NOMOR 6 DESEMBER 2021 \\ ISSN : 2303-1514 | E-ISSN : 2598-5949 \\ DOI : http://dx.doi.org/10.33578/jpfkip.v10i6.8395 \\ https://primary.ejournal.unri.ac.id/index.php/JPFKIP}

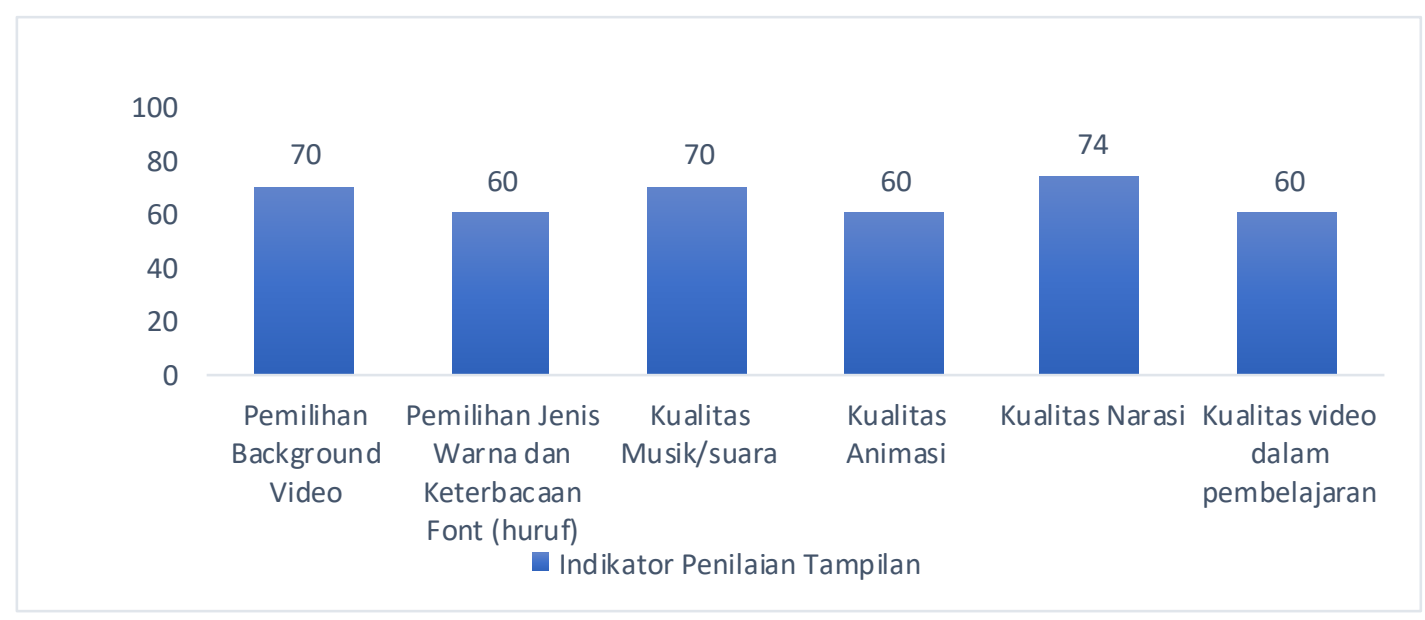

Gambar 1. Hasil Penilaian Validasi Aspek Tampilan Draft 1

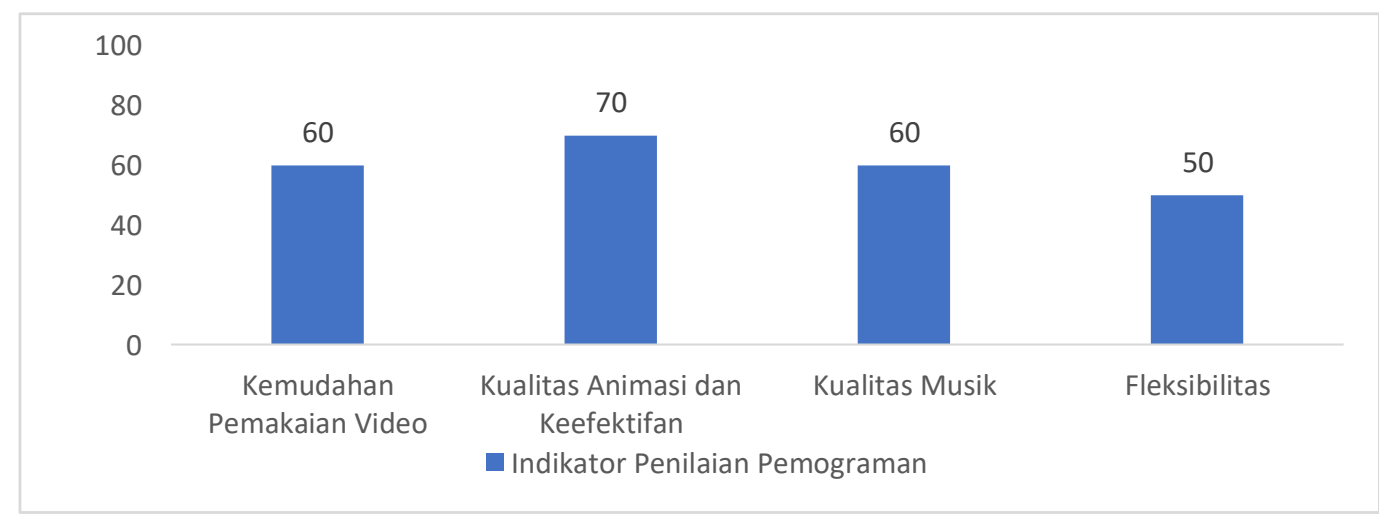

Gambar 2. Hasil Penilaian Validasi Aspek Pemograman Draft 1

Grafik validasi ahli media menjelaskan bahwa garis $\mathrm{X}$ merupakan tahapan validasi yang terdiri dari dua aspek penilaian yaitu aspek tampilan dengan enam indikator dan aspek pemograman empat indikator. Garis Y menunjukkan nilai dari setiap validasi. Penilaian dari segi tampilan memperoleh memperoleh nilai rata-rata $66.0 \%$ dan penilaian dari segi pemograman yaitu $60.0 \%$. Berdasarkan analisis data skor rata-rata total diperoleh persentase 63.0\% dengan kriteria kualitatif cukup layak digunakan. 


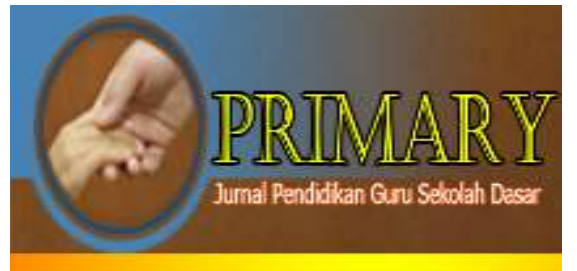

\section{PRIMARY: JURNAL PENDIDIKAN GURU SEKOLAH DASAR \\ VOLUME 10 NOMOR 6 DESEMBER 2021 \\ ISSN : 2303-1514 | E-ISSN : 2598-5949 \\ DOI : http://dx.doi.org/10.33578/jpkip.v10i6.8395 \\ https://primary.ejournal.unri.ac.id/index.php/JPFKIP}

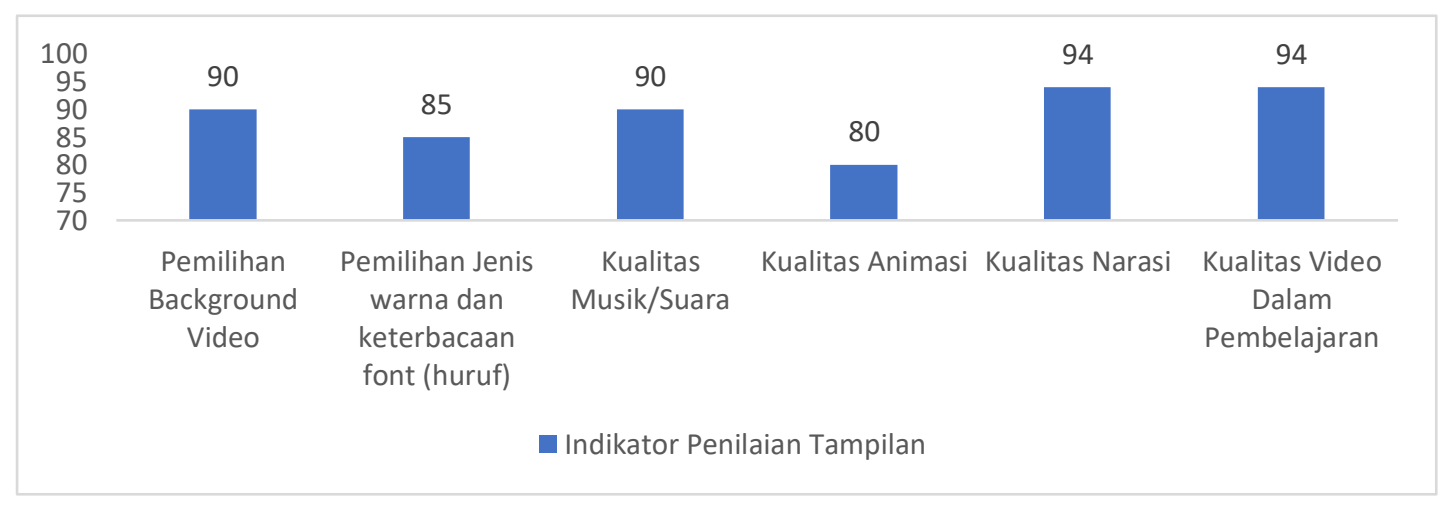

Gambar 3. Hasil Penilaian Validasi Aspek Tampilan Draft 2

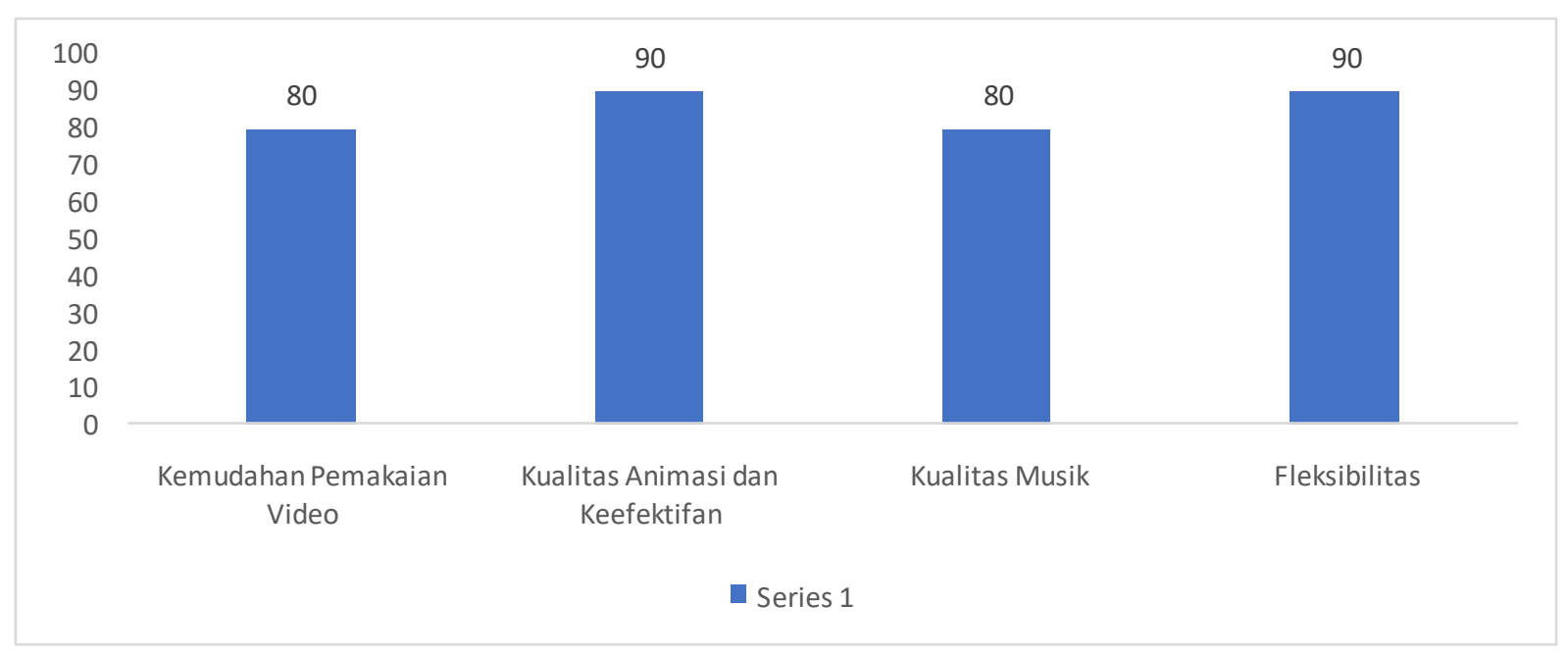

\section{Gambar 4. Hasil Penilaian Validasi Aspek Pemograman Draft 2}

Grafik validasi ahli media menjelaskan bahwa garis $\mathrm{X}$ merupakan tahapan validasi yang terdiri dari dua aspek penilaian yaitu aspek tampilan dengan enam indikator dan aspek pemograman empat indikator. Garis Y menunjukkan nilai dari setiap validasi. Penilaian dari segi tampilan memperoleh memperoleh nilai rata-rata $88,8 \%$ dan penilaian dari segi pemograman yaitu $85, \%$. Berdasarkan analisis data skor rata-rata total diperoleh persentase $87, \%$ dengan kriteria kualitatif sangat layak digunakan. Materi bertujuan untuk mengetahui tingkat kevalidan atau keabsahan media pembelajaran, untuk mendapatkan informasi, kritik, dan saran agar media video animasi berbasis kinemaster yang dikembangkan menjadi produk yang berkualitas secara aspek materi. Adapun hasil validasi yang diperoleh oleh ahli materi, sebagai berikut : 


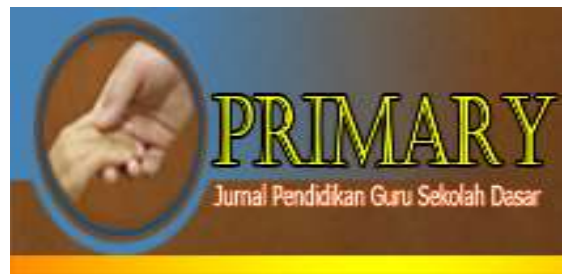

\section{PRIMARY: JURNAL PENDIDIKAN GURU SEKOLAH DASAR \\ VOLUME 10 NOMOR 6 DESEMBER 2021 \\ ISSN : 2303-1514 | E-ISSN : 2598-5949 \\ DOI : http://dx.doi.org/10.33578/jpfkip.v10i6.8395 \\ https://primary.ejournal.unri.ac.id/index.php/JPFKIP}

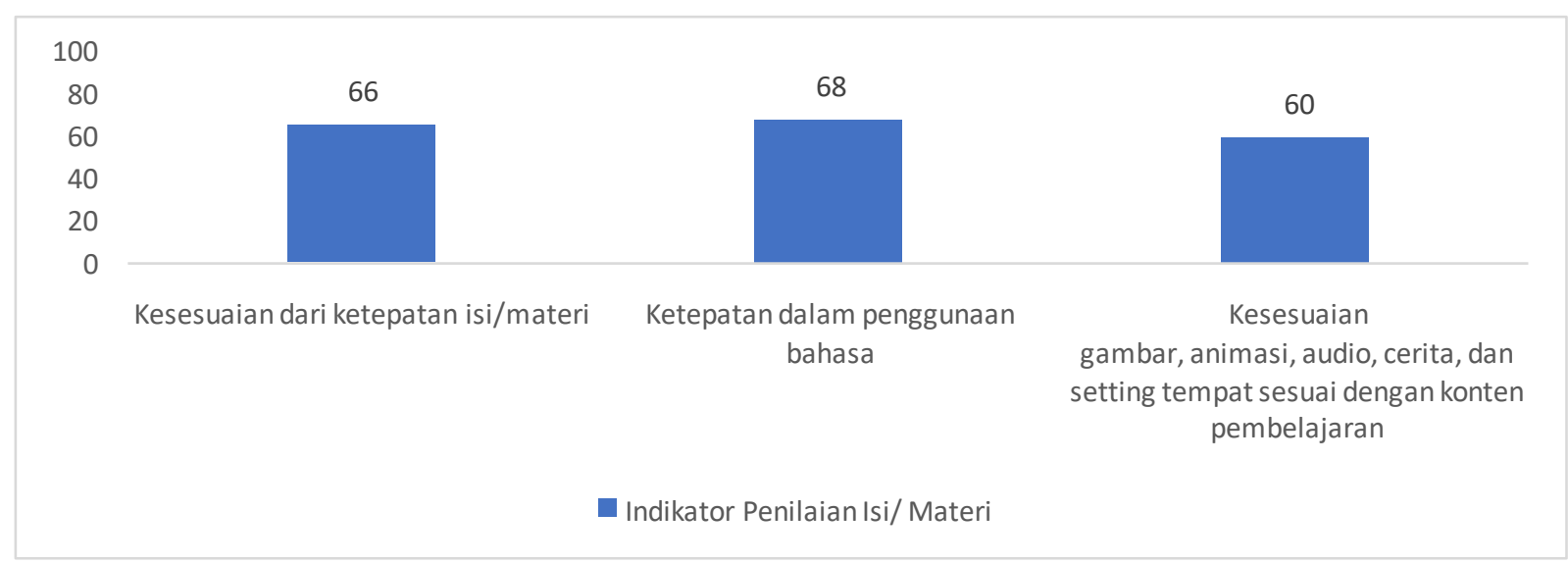

Gambar 5. Hasil Penilaian Validasi Aspek Isi/Materi Draft 1

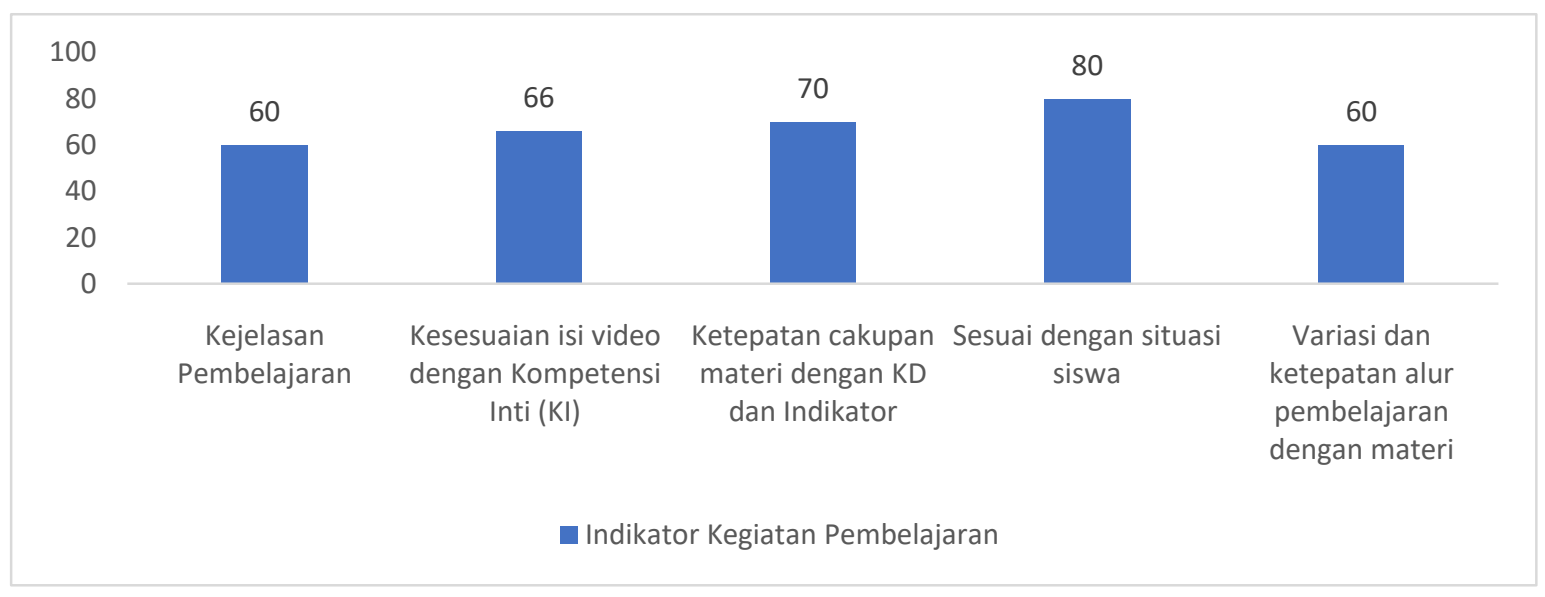

Gambar 6. Hasil Penilaian Validasi Aspek Kegiatan Pembelajaran Draft 1

Grafik validasi ahli materi menjelaskan bahwa garis $\mathrm{X}$ merupakan tahapan validasi yang terdiri dari dua aspek penilaian yaitu aspek Isi/materi dengan tiga indikator dan aspek kegiatan pembelajaran dengan lima indikator. Garis Y menunjukkan nilai dari setiap validasi. Penilaian dari segi Isi/materi memperoleh nilai rata-rata yaitu $64.7 \%$ dan penilaian dari segi kegiatan pembelajaran yaitu $68 \%$. Berdasarkan analisis data skor rata-rata total diperoleh persentase $66.4 \%$ dengan kriteria kualitatif layak digunakan. Grafik validasi ahli materi menjelaskan bahwa garis X merupakan tahapan validasi yang terdiri dari dua aspek penilaian yaitu aspek isi/materi dengan tiga indikator dan aspek kegiatan pembelajaran dengan lima indikator. Garis Y menunjukkan nilai dari setiap validasi. Penilaian dari segi isi/materi memperoleh nilai rata-rata yaitu $8,6 \%$ dan penilaian dari segi kegiatan pembelajaran yaitu 87,2. Berdasarkan analisis data skor rata-rata total diperoleh persentase $86,6 \%$ dengan kriteria kualitatif yaitu sangat layak digunakan.

f) Ujicoba Produk

Video pembelajaran yang telah divalidasi oleh ahli media dan ahli materi pembelajaran selanjutnya diuji cobakan pada peserta didik. Uji coba produk dilakukan untuk mengetahui 
keefektifan dalam penggunaan media video pembelajaran animasi berbasis kinemaster pada mata pelajaran IPA dengan materi Gaya dan Gerak Benda layak digunakan di Sekolah Dasar. Uji coba produk merupakan bagian penting dalam penelitian pengembangan yang dilakukan setelah revisi desain selesai. Uji coba produk dimaksudkan untuk mengumpulkan data yang dapat digunakan sebagai dasar untuk menetapkan tingkat efektivitas, efisiensi, dan daya tarik produk yang dihasilkan.

Uji coba produk dilakukan dengan cara uji coba kelompok kecil, pada tahap ini pengujian dilakukan di SDN Kedaleman IV dengan 28 responden. Sedang ujicoba lapangan dilakukan dengan beberapa sekolah dengan jumlah 111 peserta didik. Sistem pembelajaran yang dilakukan secara daring dengan menggunakan aplikasi googlemeet.

\section{Pembahasan}

Media dapat diartikan perantara guru untuk dapat menggunakan media dalam menyampaikan materi kepada peserta didik. Media video pembelajaran dipilih karena guru dapat mengoperasikan media dengan mudah baik secara online maupun secara offline. Penelitian ini mengembangkan video pembelajaran animasi berbasis kinemaster pada materi gaya dan gerak benda dikelas IV SD.Tahapan dalam mengembangkan media video pembelajaran animasi diantaranya tahap potensi dan masalah, pengumpulan informasi, desain produk, validasi desain, revisi desain, uji coba produk, dan revisi setelah uji coba. Tahapan pengembangan ini dilakukan untuk mengetahui efektivitas produk yang dikembangkan.

Berdasarkan hasil observasi potensi yang dimiliki terdapat sarana yang mumpuni untuk mengembangkan media berupa video, sebab SDN Kedaleman IV memiliki beberapa fasilitas berupa jaringan internet, komputer, proyektor, dan speaker. Guru kebanyakan menggunakan media gambar dan powerpoint untuk menyampaikan pesan kepada peserta didik. Sehingga dengan adanya pengembangan media membuat pembelajaran lebih menarik. Pemilihan media sangat penting untuk menarik perhatian siswa dengan animasi yang lebih variatif untuk mengetahui keefektifan belajar peserta didik. (Fawziah, dkk 2019)

Desain produk juga memperhatikan komponen inti, kompetensi dasar, indikator, dan tujuan pembelajaran pada kurikulum 2013. Peneliti juga membuat flowchart, storyboard, dan mempersiapkan skrip skrip untuk memudahkan dalam pengembangan media video ini. Desain yang dipersiapkan lainnya mengumpulkan bahan grafis seperti gambar, video animasi, suara, musik dan background sebagai bahan pendukung dalam pembuatan video pembelajaran sebelum produksi media dimulai.

Uji validasi yang telah dilakukan oleh ahli media dari segi tampilan memperoleh nilai rata-rata yaitu $88,8 \%$ dan penilaian dari segi pemograman yaitu $85 \%$. Berdasarkan analisis data skor rata-rata total diperoleh persentase $87 \%$ dengan kriteria kualitatif yaitu sangat layak digunakan untuk media video animasi berbasis kinemaster.

Uji validasi yang telah dilakukan oleh ahli materi dari segi isi/materi memperoleh nilai rata-rata yaitu $89,1 \%$ dan penilaian dari segi kegiatan pembelajaran $87 \%$. Berdasarkan analisis dari data skor rata-rata total diperoleh persentase $88 \%$ dengan kriteria kualitatif yaitu sangat layak digunakan.

Uji coba yang dilakukan secara daring melalui aplikasi google meet dengan beberapa sekolah yang sudah terjadwalkan dalam pembelajaran secara daring dengan jumlah siswa sebanyak 139 peserta didik. Peserta didik ikut terlibat dalam penggunaan media pembelajaran yang dapat dilakukan secara mandiri, menarik, dan menyenangkan. Ujicoba yang telah dilaksanakan dengan menggunakan video pembelajaran animasi berbasis kinemaster, guru kelas IV memberikan respon terhadap media ini. Respon guru yang telah dilakukan oleh guru kelas IV pada SDN Kedaleman IV, SDN Cibeber II, dan SDN Cikerut dari aspek materi dan pembelajaran yaitu $94,3 \%$ dan aspek media memiliki persentase $86,8 \%$. Rata-rata persentase respon guru terhadap media video yaitu $91 \%$ 
dengan kategori sangat baik digunakan dalam pembelajaran dengan bantuan media video animasi berbasis kinemaster.

Berdasarkan respon siswa terhadap video pembelajaran animasi berbasis kinemaster, respon siswa pada aspek hasil program memperoleh persentase $97.3 \%$ dan aspek efektivitas bagi peserta didik dengan persentase $96 \%$. Rata-rata keseluruhan respon peserta didik yaitu 97\% dengan kriteria kualitatif yaitu peserta didik sangat memahami materi dan sangat baik dalam menggunakan media pembelajaran animasi.

\section{SIMPULAN DAN REKOMENDASI}

Berdasarkan data hasil penelitian dan pembahasan yang telah digunakan maka dapat ditarik kesimpulan bahwa :

1. Penerapan tahapan pengembangan media video pembelajaran animasi berbasis kinemaster pada kelas IV mata pelajaran IPA yaitu sangat layak digunakan dan setelah uji coba diperoleh media video pembelajaran animasi dalam kategori sangat baik, sehingga tidak diperlukan evaluasi atau perbaikan.

2.Produk pengembangan video kinemaster memiliki tiga langkah yaitu pra produksi, produksi, dan pasca produksi. Hasil produksi ini berupa video pembelajaran IPA yang di burning kedalam CD.

3. Pengembangan video pembelajaran animasi pada mata pelajaran IPA dengan materi gaya dan gerak benda dapat meningkat pemahaman siswa pada materi tersebut. Adapun capaian hasil setelah menggunakan media pembelajaran dalam uji lapangan memperoleh rata-rata $90.6 \%$ dengan kriteria kualitatif sangat baik.

4. Efektivitas penggunaan media video pembelajaran animasi berbasis kinemaster terhadap mata pelajaran IPA yaitu peserta didik sangat memahami materi dan sangat tertarik untuk belajar IPA sehingga efektif digunakan dalam proses pembelajaran dengan media video animasi berbasis kinemaster. Adapun aspek materi dan pembelajaran yaitu $94.3 \%$ dan aspek media memiliki persentase $86.8 \%$. Rata-rata persentase respon guru terhadap media video yaitu $91 \%$ dengan kategori sangat baik, serta rata-rata keseluruhan respon peserta didik yaitu 97\% dengan kriteria kualitatif yaitu peserta didik sangat memahami materi dan sangat baik dalam menggunakan media pembelajaran animasi pada mata pelajaran IPA dengan materi gaya dan gerak benda di kelas IV SD.

\section{SARAN}

Berdasarkan hasil penelitian, pembahasan, dan simpulan diatas maka saran yang dapat diberikan pada penelitian ini adalah :

1. Sesuai dengan hasil penelitian, bahwa media video pembelajaran animasi berbasis kinemaster pada materi gaya dan gerak benda berdasarkan pengujian hasil dari peserta didik sangat layak untuk digunakan. Oleh karena itu dapat diterapkan dalam proses pembelajaran disekolah baik secara daring maupun secara tatap muka.

2. Mengujicobakan kegiatan pembelajaran menggunakan aplikasi kinemaster pada materi gaya dan gerak benda dengan output youtube pada subjek penelitian yang berbeda.

3. Bagi peneliti selanjutnya, diharapkan melakukan tahapan penelitian dan pengembangan model ADDIE sesuai tahapan serta mengujicobakan pada peserta didik untuk mengetahui pengaruh media pembelajaran yang dibuat.

\section{DAFTAR PUSTAKA}

Adi, C. (2019). Pengembangan Media Dan Sumber Belajar: Teori dan Prosedur. Laksita Indonesia, (August), 26. Retrieved from file:///E:/Renc Skripsi/AniCahyadiPengembanganMedia. pdf

Fawziah, E., Yani, A. P., \& Idrus, I. (2019). Implementasi Media Pembelajaran Berbasis Android Pada Materi Keanekaragaman Hayati Di Sman 08 Kota Bengkulu. Diklabio: Jurnal Pendidikan Dan Pembelajaran Biologi, 2(2), 


\section{PRIMARY: JURNAL PENDIDIKAN GURU SEKOLAH DASAR \\ VOLUME 10 NOMOR 6 DESEMBER 2021 \\ ISSN : 2303-1514 | E-ISSN : 2598-5949 \\ DOI : http://dx.doi.org/10.33578/jpfkip.v10i6.8395 \\ https://primary.ejournal.unri.ac.id/index.php/JPFKIP}

https://doi.org/10.33369/diklabio.2.2.7379

Hamdayan, J. (2017). Model dan Metode Pembelajaran Kreatif dan Berkarakter (pp. 201, 204-205). pp. 201, 204-205.

Hermiyanty, Wandira Ayu Bertin, D. S. (2017). Pembelajaran IPA Sekolah Dasar. In Journal of Chemical Information and Modeling (Vol. 8).

Musdayat, I. (2017). Pengembangan Media Pembelajaran Berbasis Video. Jurnal Dimensi Pendidikan Dan Pembelajaran, Vol. 3, pp. 82-88.

Oktaviani, R. T. (2019). Pemanfaatan Video sebagai Media Pembelajaran dalam Pendidikan dan Pelatihan ( Diklat ). MADIKA: Media Informasi Dan Komunikasi Diklat Kepustakawanan, 5(1), 91-94.

Sulthon, S. (2017). Pembelajaran IPA yang Efektif dan Menyenangkan bagi Siswa
MI. ELEMENTARY: Islamic Teacher Journal, $4(1)$. https://doi.org/10.21043/elementary.v4i1. 1969

Sumarni, Halidjah, S., \& Kresnadi, H. (2015). Peningkatan Hasil Belajar Siswa Menggunakan Metode Kerja Kelompok Dalam Pembelajaran Ipa Di Sekolah Dasar. Jurnal Pendidikan Dan Pembelajaran Khatulistiwa, 4(1), 1-10. Retrieved from Sumarni, Siti Halidjah, Hery Kresnadi

Tegeh, I. M., \& Kirna, I. M. (2013). Pengembangan Bahan Ajar Metode Penelitian Pendidikan dengan ADDIE Model. Jurnal IKA, 11(1), 12-26. 